\title{
EVALUATION OF PRESERVATION METHODS FOR SELECTED NUTRIENTS IN GROUND WATER AT THE IDAHO NATIONAL ENGINEERING LABORATORY, IDAHO
}

\section{By ROY C. BARTHOLOMAY and LINDA M. WILLIAMS}

\section{U.S. GEOLOGICAL SURVEY}

Water-Resources Investigations Report 96-4260

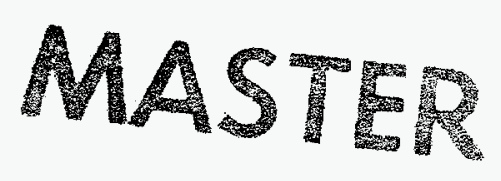

Prepared in cooperation with the U.S. DEPARTMENT OF ENERGY

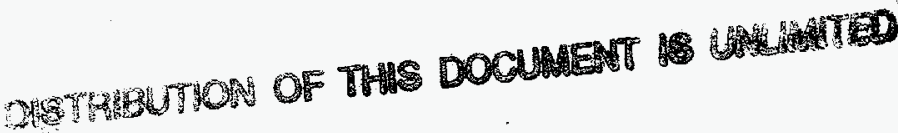

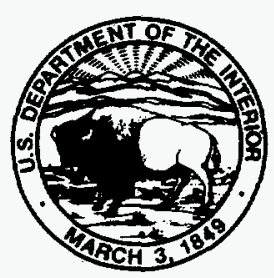
October 1996 


\title{
U.S. DEPARTMENT OF THE INTERIOR \\ BRUCE BABBITT, Secretary
}

\author{
U.S. GEOLOGICAL SURVEY \\ Gordon P. Eaton, Director
}

Any use of trade, product, or firm names is for descriptive purposes

only and does not imply endorsement by the U.S. Government.

For additional information write to:

U.S. Geological Survey

INEL, MS 4148

P.O. Box 2230

Idaho Falls, ID 83403-2230
Copies of this report can be purchased from:

\author{
U.S. Geological Survey \\ Branch of Information Services
}

Box 25286

Denver, CO 80225-0286 


\section{DISCLAMER}

Portions of this document may be illegible in electronic image products. Images are produced from the best available original document. 


\section{DISCLAIMER}

This report was prepared as an account of work sponsored by an agency of the United States Government. Neither the United States Government nor any agency thereof, nor any of their employees, make any warranty, express or implied, or assumes any legal liability or responsibility for the accuracy, completeness, or usefulness of any information, apparatus, product, or process disclosed, or represents that its use would not infringe privately owned rights. Reference herein to any specific commercial product, process, or service by trade name, trademark, manufacturer, or otherwise does not necessarily constitute or imply its endorsement, recommendation, or favoring by the United States Government or any agency thereof. The views and opinions of authors expressed herein do not necessarily state or reflect those of the United States Government or any agency thereof. 


\section{CONTENTS}

Abstract $\ldots \ldots \ldots \ldots \ldots \ldots \ldots \ldots \ldots \ldots \ldots \ldots \ldots \ldots \ldots \ldots \ldots \ldots \ldots \ldots \ldots \ldots \ldots$

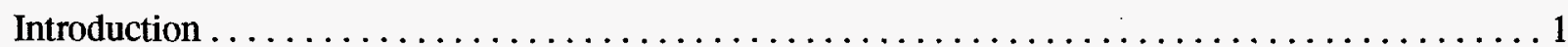

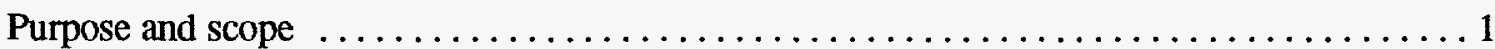

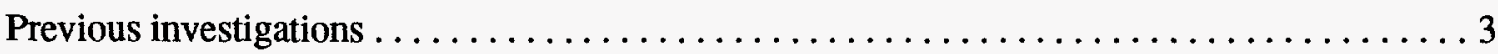

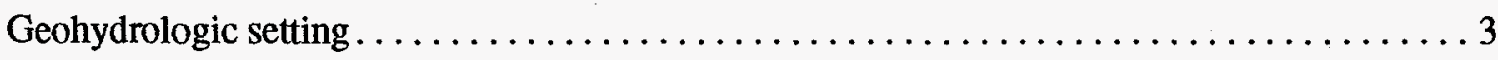

Acknowledgments. ..................................

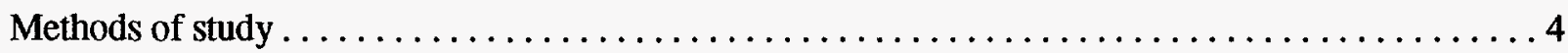

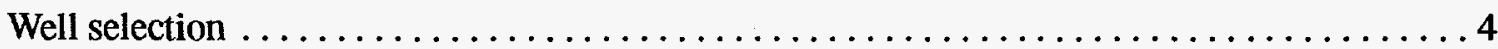

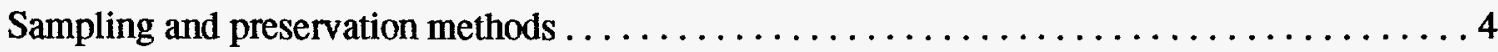

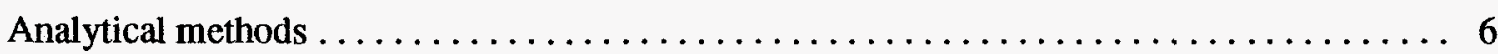

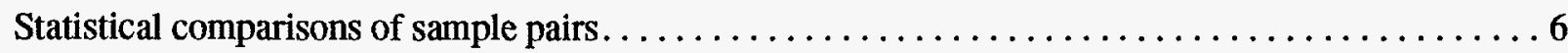

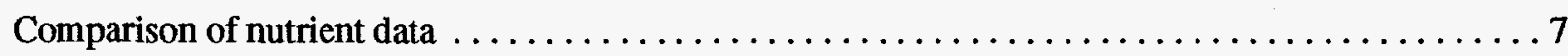

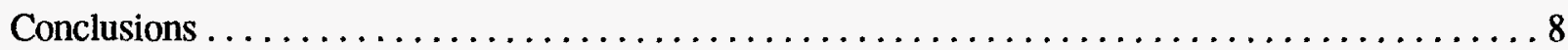

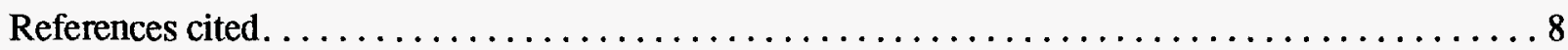

\section{FIGURES}

Figures 1-2. Maps showing:

1. Location of the Idaho National Engineering Laboratory, selected facilities, and

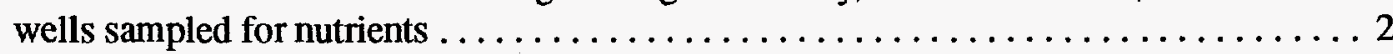

2. Location of wells sampled for nutrients, Naval Reactors Facility and vicinity,

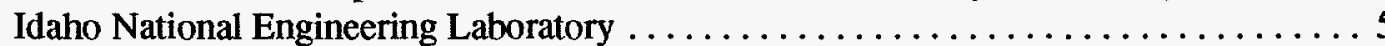

\section{TABLES}

1. Linear least-squared equations used for determining the most probable deviations for results of nutrient analyses

2. Comparison of ammonia results obtained from field-filtered samples preserved with mercuric chloride and chilling and samples preserved by chilling only, Idaho National Engineering Laboratory . .

3. Comparison of nitrite results obtained from field-filtered samples preserved with mercuric chloride and chilling and samples preserved by chilling only, Idaho National Engineering Laboratory.

4. Comparison of nitrite plus nitrate results obtained from field-filtered samples preserved with mercuric chloride and chilling and samples preserved by chilling only, Idaho National Engineering Laboratory. 
5. Comparison of orthophosphate results obtained from field-filtered samples preserved with mercuric chloride and chilling and samples preserved by chilling only, Idaho National

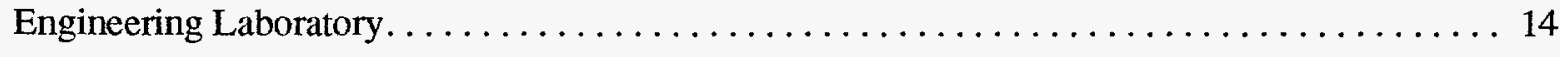

6. Ammonia results obtained from field-filtered samples preserved with sulfuric acid and chilling, samples preserved with mercuric chloride and chilling, and samples preserved by chilling only,

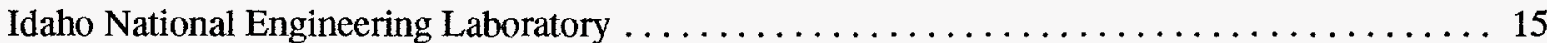

7. Nitrite plus nitrate results obtained from field-filtered samples preserved with sulfuric acid and chilling, samples preserved with mercuric chloride and chilling, and samples preserved by chilling only, Idaho National Engineering Laboratory

\section{CONVERSION FACTORS, VERTICAL DATUM, AND ABBREVIATED UNITS}

\section{Multiply}

inch (in.)

foot (ft)

mile (mi)

square mile $\left(\mathrm{mi}^{2}\right)$

pound (lb)
$\frac{\mathrm{By}}{25.4}$

0.3048

1.609

2.590

0.4536
To obtain millimeter meter kilometer square kilometer kilogram

For temperature, degrees Celsius $\left({ }^{\circ} \mathrm{C}\right)$ may be converted to degrees Fahrenheit $\left({ }^{\circ} \mathrm{F}\right)$ by using the formula ${ }^{\circ} \mathrm{F}=(1.8)\left({ }^{\circ} \mathrm{C}\right)+32$.

Sea level: In this report, "sea level" refers to the National Geodetic Vertical Datum of 1929-a geodetic datum derived from a general adjustment of the first-order level nets of both the United States and Canada, formerly called Sea Level Datum of 1929.

Abbreviated units used in report: $\mathrm{mg} / \mathrm{L}$ (milligram per liter), $\mu \mathrm{m}$ (micrometer). 


\title{
Evaluation of Preservation Methods for Selected Nutrients in Ground Water, Idaho National Engineering Laboratory, Idaho
}

\author{
by Roy C. Bartholomay and Linda M. Williams
}

\begin{abstract}
Water from 28 wells completed in the Snake River Plain aquifer at the Idaho National Engineering Laboratory (INEL) was sampled as part of the U.S. Geological Survey's quality-assurance program to determine the effect of different preservation methods on nutrient concentrations. Samples were preserved with filtration and with mercuric chloride and chilling, chilling only, or sulfuric acid and chilling. The samples were analyzed for ammonia, nitrite, nitrite plus nitrate, and orthophosphate by the U.S. Geological Survey National Water Quality Laboratory. The study was done in cooperation with the U.S. Department of Energy.

The comparison between samples preserved with mercuric chloride and chilling and samples preserved by chilling only showed that all sample pairs were in statistical agreement. Results for ammonia and nitrite plus nitrate samples preserved with sulfuric acid and chilling were within the 95-percent confidence level of the results for the samples preserved by the other two methods and can be considered equivalent to them. Results of this study indicate that discontinuing the use of mercuric chloride as a preservation method for nutrients in water samples will not affect the comparability of data collected at the INEL before and after October 1, 1994.
\end{abstract}

\section{INTRODUCTION}

The Idaho National Engineering Laboratory (INEL), encompassing about $890 \mathrm{mi}^{2}$ of the eastern Snake River Plain in southeastem Idaho (fig. 1), is operated by the U.S. Department of
Energy (DOE). INEL facilities are used in the development of peacetime atomic-energy applications, nuclear safety research, defense programs, and advanced energy concepts. Liquid-waste disposal has resulted in detectable concentrations of several waste constituents in water in the Snake River Plain aquifer underlying the INEL. The U.S. Geological Survey (USGS) project office at the INEL provides an independent assessment of the migration and fate of waste constituents in water in the Snake River Plain aquifer.

Wastewater containing nitrate was injected to the Snake River Plain aquifer through the Idaho Chemical Processing Plant (ICPP) disposal well from 1952 to February 1984 and was discharged to the ICPP infiltration ponds after February 1984. An average of $56,000 \mathrm{lb}$ of nitrate was discharged annually to the ICPP infiltration ponds during 1989-91 (Bartholomay and others, 1995, p. 33). Background concentrations of nitrate as nitrogen in the Snake River Plain aquifer at the INEL generally are less than $1.4 \mathrm{mg} / \mathrm{L}$ (Orr and others, 1991, p. 46). Possible sources of excess nitrate in the aquifer at the INEL are the disposal of chemical wastes, such as nitric acid, and the disposal of sewage at the various facilities. The use of nitrogenous fertilizers in the farming areas near the INEL boundary also may be a source of excess nitrate in the aquifer.

\section{Purpose and Scope}

The USGS project office at the INEL collects water samples for nutrient analyses as part of the ongoing assessment of water quality in the Snake River Plain aquifer. Nutrients included in analyses 


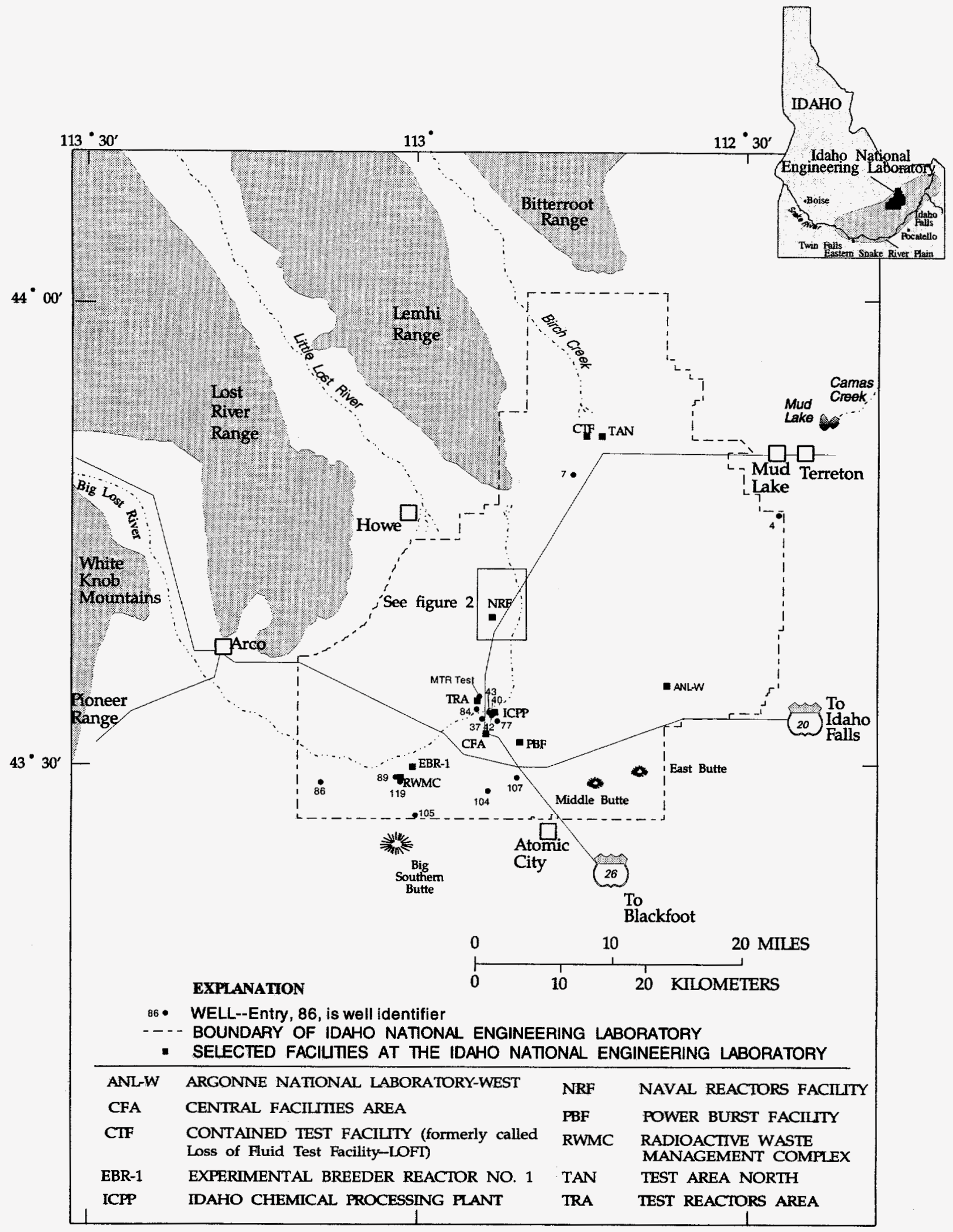

Figure 1. Location of the Idaho National Engineering Laboratory, selected facilities, and wells sampled for nutrients. 
are dissolved ammonia, nitrite, nitrite plus nitrate, and orthophosphate. In the past, samples were preserved by filtration and treatment with mercuric chloride and chilling to $4^{\circ} \mathrm{C}$. Since October 1 , 1994, when the USGS Water Resources Division discontinued the use of mercuric chloride to reduce the hazards of handling this toxic material (D.A. Rickert, USGS, written commun., 1994), samples have been preserved either by chilling to $4^{\circ} \mathrm{C}$, or by treatment with sulfuric acid and chilling to $4^{\circ} \mathrm{C}$. Because of the change in preservation methods, the INEL project office evaluated the three preservation methods to assure that nutrient data collected after October 1, 1994, are comparable to data collected prior to October 1, 1994.

This study was done as part of the USGS's quality-assurance program in cooperation with the DOE to determine the effect of different preservation methods on nutrient concentrations in ground water. Water samples were preserved by filtering through a 0.45 micron filter and treating with mercuric chloride and chilling, chilling only, or sulfuric acid and chilling. Samples were analyzed for nutrients by the USGS National Water Quality Laboratory (NWQL).

\section{Previous Investigations}

The USGS has conducted several studies concerning the quality assurance of water data at the INEL. Comparative studies to determine agreement among results for water-sample pairs analyzed by laboratories involved in the INEL project office quality-assurance program were summarized by Wegner (1989) and Williams (1996). Additional quality-assurance studies by personnel at the INEL project office include an evaluation of field-sampling and preservation methods for strontium-90 (Cecil and others, 1989), a comparison of different pump types used for sampling purgeable organic compounds (Knobel and Mann, 1993), and an analysis of tritium and strontium- 90 concentrations in water from wells after purging different borehole volumes (Bartholomay, 1993).

Patton and Truitt (1995) conducted a study to find out if the addition of biocides-mercuric (II) chloride or sulfuric acid-to field-filtered samples resulted in improved stability of nutrient species during storage at $4^{\circ} \mathrm{C}$ for 1 month. The study, which included water samples from 11 surfacewater sites and 3 ground-water sites, indicated that when biota were removed from samples at the collection site by $0.45-\mu \mathrm{m}$ membrane filtration, subsequent addition of biocides was not needed. These results provided the basis for the USGS Office of Water Quality technical memorandum (D.A. Rickert, USGS, written commun., 1994) to discontinue adding mercuric chloride to nutrient samples as a field preservative. The former USGS policy of preserving nutrient samples with mercuric chloride at the collection site was based on a prior study by Fishman and others (1986).

Although bulk samples collected for the Fishman study were filtered before they were split into small bottles and preserved with biocides, the $10-\mu \mathrm{m}$ nominal pore size of the filters used was too large to retain bacteria and phytoplankton. Because of the large pore size of the filters, water in the smallbottle splits probably retained much of its prefiltration biological activity, and hence the necessity of adding a biocide for 16-day storage stability is unsurprising and does not contradict the more recent work of Patton and Truitt (1995).

\section{Geohydrologic Setting}

The eastern Snake River Plain is a northeasttrending structural basin about $200 \mathrm{mi}$ long and 50 to $70 \mathrm{mi}$ wide (fig. 1). The basin, bounded by faults on the northwest and downwarping and faulting on the southeast, has been filled with basaltic lava flows interbedded with terrestrial sediments (Whitehead, 1986). Individual basalt flows average 20 to $25 \mathrm{ft}$ in thickness with an aggregate thickness in places of several thousand feet. In areas of alluvial fan deposits, the sediments are composed primarily of sand and gravel, whereas in the areas where streams were dammed by basalt flows, the sediments are predominately silt and clay (Garabedian, 1986). The basaltic lava flows and interbedded sedimentary deposits combine to form the Snake River Plain aquifer, which is the main source of water on the plain. The altitude of the water table for the Snake River Plain aquifer in July 1991 ranged from about $4,585 \mathrm{ft}$ above sea level in the northem part of the INEL to about $4,425 \mathrm{ft}$ in the southwestem part (Barthol- 
omay and others, 1995, p. 18). The corresponding depths to water below land surface ranged from about $200 \mathrm{ft}$ in the northern part of the INEL to more than $900 \mathrm{ft}$ in the southeastern part.

Recharge to the Snake River Plain aquifer is principally from infiltration of applied irrigation water, infiltration of streamflow, and ground-water inflow from adjoining mountain drainage basins. Some recharge may occur from direct infiltration of precipitation, although the small annual precipitation ( 8 in. at the INEL), evapotranspiration, and the depth to water (in places exceeding $900 \mathrm{ft}$ ) probably minimize this source of recharge (Orr and Cecil, 1991, p. 22-23).

The Big Lost River drains more than $1,400 \mathrm{mi}^{2}$ of mountainous area that includes parts of the Lost River Range and the Pioneer Range and White Knob Mountains west of the INEL (fig. 1). Water in the Big Lost River infiltrates to the Snake River Plain aquifer along its channel and at sinks and playas. Since 1958, excess runoff has been diverted to spreading areas in the southwestern part of the INEL, where much of the water rapidly infiltrates to the aquifer. Other surface drainages that recharge the Snake River Plain aquifer at the INEL include Birch Creek, Little Lost River, and Camas Creek (fig. 1) (Bartholomay and others, 1995, p. 18).

\section{Acknowledgments}

The authors gratefully acknowledge LeRoy L. Knobel, Gary S. Lords, Michael F. Reed, and Betty $J$. Tucker of the USGS for help in collecting the water samples. The authors are grateful to Charles J. Patton and Michael J. Liszewski of the USGS for technically reviewing the report.

\section{METHODS OF STUDY}

\section{Well Selection}

Samples were collected from 28 selected wells; 15 in various locations throughout INEL (fig. 1), and 13 near the Naval Reactors Facility (NRF) (fig. 2). The wells were selected to obtain a range of nutrient concentrations representative of the water at the INEL. Historically, water from USGS 43, near the ICPP (fig. 1), has had the highest concentration of nitrate at the INEL; and water from USGS 15 and 17, north of the NRF (fig. 2), has had the lowest concentrations at the INEL.

\section{Sampling and Preservation Methods}

The methods used for collecting water samples generally followed guidelines established by the USGS (Stevens and others, 1975; Wood, 1981; Claassen, 1982; and Hardy and others, 1989). Twenty-four ground-water monitoring wells were sampled using dedicated submersible pumps, and four production wells (NRF-1, $-2,-3$, and -4 ) were sampled using line-shaft turbine pumps. The 13 wells near the NRF were sampled and analyzed for nutrients using all three preservation methodsmercuric chloride and chilling, chilling only, and sulfuric acid and chilling - because the contractor at the NRF requests acid preservation for nutrient analyses. Analyses for orthophosphate and nitrite preserved with sulfuric acid were not included in the study because they routinely are not available from the NWQL. Preservation with acid is not required at the other 15 wells; therefore, samples from those wells were treated with mercuric chloride and chilling, and chilling only.

Samples were collected either from a portable sampling apparatus at the wells with dedicated submersible pumps or from sampling ports on the discharge lines of the turbine pumps. All portable equipment was decontaminated before sampling at each site. Pre-cleaned Tygon tubing was used to connect a disposable capsule filter to the sample ports. One liter of well water was run through the 0.45 -micron filters prior to sample collection. The nutrient samples were collected sequentially: the samples to be preserved with mercuric chloride and chilling were collected first, the samples to be chilled only were collected next, and the samples to be preserved with sulfuric acid and chilling were collected last. After collection and addition of either mercuric chloride or sulfuric acid, sample containers were sealed with laboratory film, labeled, and stored under secure conditions in a refrigerator at $4^{\circ} \mathrm{C}$. The water samples were placed in ice chests, sealed, and shipped as soon as possible by overnight-delivery mail to the NWQL. 


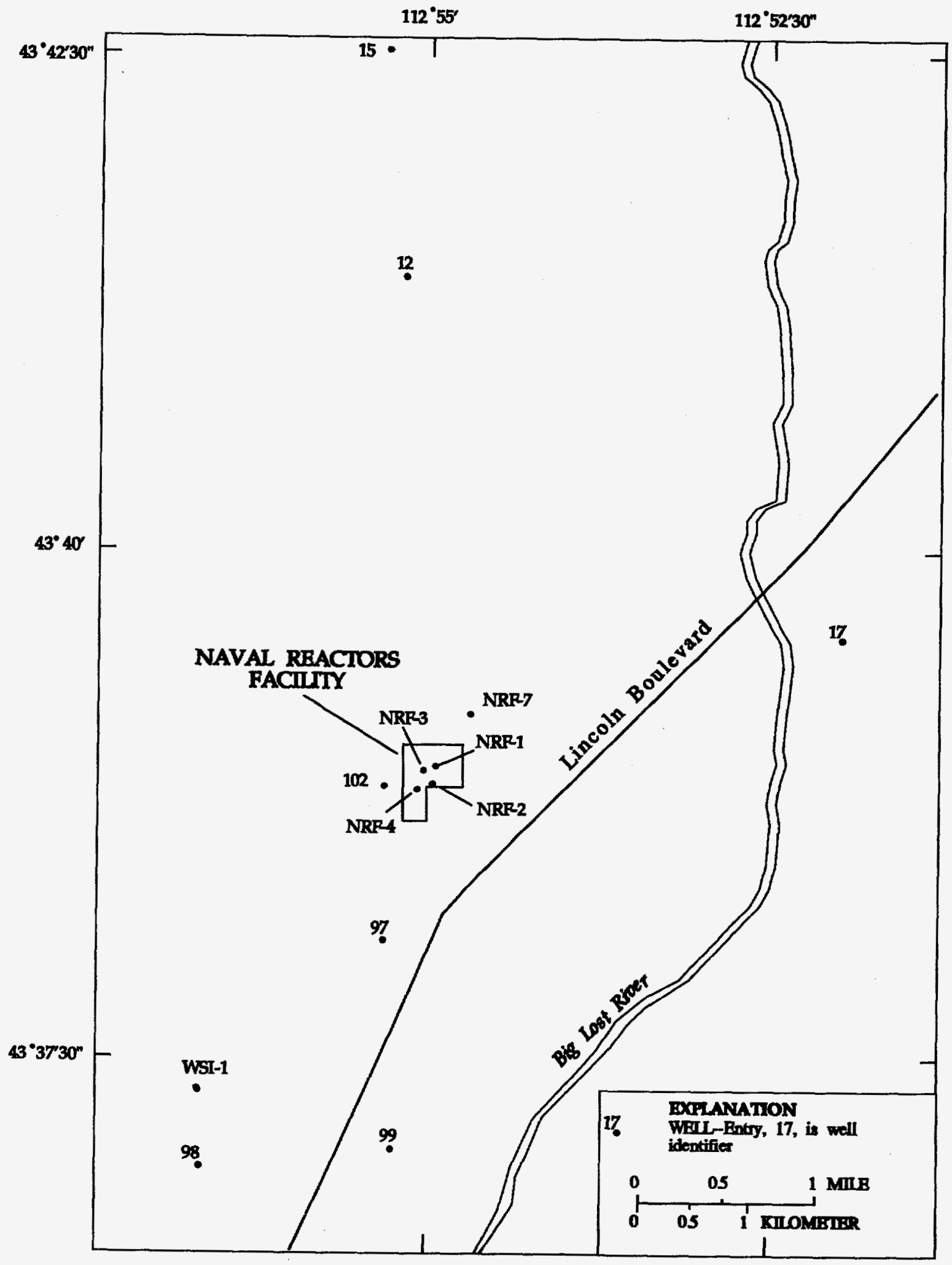

Figure 2. Location of wells sampled for nutrients, Naval Reactors Facility and vicinity, Idaho National Engineering Laboratory. 
Conditions at the well during sample collection were recorded in a field logbook and a chain-ofcustody record was used to track samples from the time of collection until delivery to the analyzing laboratory. These records are available for inspection at the USGS project office at the INEL.

\section{Analytical Methods}

Water samples were analyzed for ammonia, nitrite, nitrite plus nitrate, and orthophosphate by the NWQL using methods described by Fishman (1993). The laboratory methods used for each constituent were consistent for each preservation type. Laboratory instruments were calibrated using appropriate standards for each preservation type (J. Vasquez, USGS, oral commun., 1995).

\section{STATISTICAL COMPARISONS OF SAMPLE PAIRS}

If the standard deviations are known, it is possible to determine, within specified confidence levels, whether the results of a pair of samples are statistically equal. If the standard deviations are unknown, approximations of the standard deviations are used for the statistical comparison. The comparison can be made using an adaptation of the equation to determine the standard deviate, $\mathrm{Z}$, or the number of standard deviations the variable deviates from the mean (Volk, 1969, p.55), where $\mathrm{Z}$ is the ratio of the absolute value of the difference of the two results and the square root of the sum of the squares of the standard deviations (the pooled standard deviation). In that way, a comparison can be made of two analytical results on the basis of the precision, or an approximation of the precision, associated with each of the results:

$$
Z=\frac{|x-y|}{\sqrt{\left(s_{x}\right)^{2}+\left(s_{y}\right)^{2}}}
$$

where:

$x$ is the result of the sample preserved with mercuric chloride,

$y$ is the result of the unpreserved sample,

$s_{x}$ is the standard deviation of $x$, and

$s_{y}$ is the standard deviation of $y$.
When the population is distributed normally and the standard deviation is known, the analytical results of sample pairs can be considered statistically equal at the 95-percent confidence level if the $\mathrm{Z}$-value is less than or equal to 1.96 . When the population is not distributed normally or an approximation of the standard deviation is used, a $\mathrm{Z}$-value less than or equal to 1.96 must be considered a guide to testing for nonequivalence. In other words, when $\mathrm{Z}$ is less than or equal to 1.96 , the results are within approximately two standard deviations of each other. Equation 1 is the equation used to compare quality-assurance data from the INEL project office (Williams, 1996) and is essentially the equation used to compare replicate data in the USGS protocol for collecting and processing surface-water samples (Horowitz and others, 1995, p. 36).

Equation 1 cannot be applied directly to results for which no standard deviations or uncertainties are reported. Because the NWQL did not report standard deviations for analyses for this study, approximations of standard deviations, or most probable deviations (MPD's), were used. The USGS Branch of Quality Assurance (BQA) conducts a Blind Sample Program (BSP) in which reference samples disguised as environmental samples are submitted to the NWQL. Maloney and others (1993) described the program and evaluated the analytical results. The BSP data are stored in the QADATA program that is available through the USGS computer network (Lucey, 1990, p 1). The data and statistical analyses included in the QADATA program are used to derive linear leastsquared equations that allow the calculation of an MPD at any concentration for most analyses. The linear least-squared equations were used to determine if the analytical results of the nutrient samples preserved with mercuric chloride and chilling and the samples preserved with chilling only were statistically equivalent by calculating an MPD for each result and substituting the MPD's for the standard deviations in equation 1 . Because these were approximate standard deviations, the Zvalue of 1.96 was considered a guide to testing for nonequivalence. The linear least-squared equations used to determine the MPD's are shown on table 1. 
Nutrient samples preserved with sulfuric acid and chilling are not included in the BSP, and therefore, cannot be compared using this method.

Comparisons of nutrient concentrations in samples preserved with mercuric chloride and chilling or chilling only are shown in tables 2-5. In many samples, the concentration of a specific constituent was less than the reporting level. If the concentrations of both samples in a pair were less than the same reporting level, it was assumed that the results were equivalent and the $\mathrm{Z}$-value was reported as a zero. If, however, the reporting levels differed, or only one of the concentrations was less than the reporting level, one of two approaches was taken. The first approach was used when either both results were less than the reporting level and the reporting levels differed, or when one result was less than the reporting level and the other was at the reporting level. The second approach was used when one result was less than the reporting level and the other exceeded the reporting level.

In the first approach, the MPD of each result was calculated at the reporting level using the linear regression equation for that analysis. To compare the two results using the precision associated with them, the deviations were multiplied by 1.96. If the range of the deviation included zero, the results were considered equivalent because any determination less than the reporting level was included in the 95-percent confidence level. For example, the results of analyses for ammonia in samples collected at USGS 4 were $<0.01 \mathrm{mg} / \mathrm{L}$ for the sample preserved with mercuric chloride and chilling and $<0.015$ for the sample preserved with chilling only (table 2 ). The linear regression equation generated MPD's of $0.02 \mathrm{mg} / \mathrm{L}$ and 0.07 $\mathrm{mg} / \mathrm{L}$, respectively. Therefore, the result of $<0.01$ $\mathrm{mg} / \mathrm{L}$ had an MPD of $1.96 \times 0.02 \mathrm{mg} / \mathrm{L}$ at the 95 -percent confidence level or $0.01 \pm 0.04 \mathrm{mg} / \mathrm{L}$; and the other result, $<0.015 \mathrm{mg} / \mathrm{L}$, had an MPD of $1.96 \times 0.07 \mathrm{mg} / \mathrm{L}$, or $0.015 \pm 0.14 \mathrm{mg} / \mathrm{L}$. Both ranges included zero; therefore, the results were considered equivalent.

In the second approach, the MPD of the numerical value and the MPD of the value of the reporting level were substituted for the results in equation 1. For example, the results of analyses for ammonia in samples collected at USGS 17 were $0.02 \mathrm{mg} / \mathrm{L}$ for the sample preserved with mercuric chloride and chilling and $<0.015$ for the sample preserved with chilling only (table 2 ). The linear regression equation generated MPD's of $0.02 \mathrm{mg} / \mathrm{L}$ and $0.07 \mathrm{mg} / \mathrm{L}$, respectively. The Z-value, calculated from equation 1 , equaled 0.07 . This value was less than 1.96 and, therefore, was within the 95-percent confidence level, so the results were considered equivalent.

\section{COMPARISON OF NUTRIENT DATA}

Nutrient concentrations in samples preserved with mercuric chloride and chilling are compared with nutrient concentrations in samples preserved by chilling only in tables $2-5$. Tables 6-7 show concentrations of nutrients in samples preserved with all three methods.

The comparison of ammonia results for samples preserved with mercuric chloride and chilling and samples preserved by chilling only (table 2) indicates that concentrations in all of the sample pairs are statistically equivalent. The correlation coefficients for ammonia show that there was high variability in the chilled-only samples in the BSP. Even though the high variability resulted in large MPD's, all the results of sample pairs analyzed for ammonia were within one standard deviation. Concentrations of ammonia in samples preserved with sulfuric acid and chilling (table 6) were within the 95-percent confidence level of the reporting levels for concentrations in samples preserved by the other two methods and also may be considered equivalent to them.

The comparison of nitrite results for samples preserved with mercuric chloride and chilling and samples preserved by chilling only (table 3 ) indicates that concentrations in all samples were less than the reporting level and are statistically equivalent. The preservation of nitrite samples with sulfuric acid and chilling was not investigated because nitrite ions are unstable in acidic solutions (Brezonik and Lee, 1966).

The comparison of nitrite plus nitrate results for samples preserved with mercuric chloride and chilling and samples preserved by chilling only (table 4) indicates that all the sample pairs are 
statistically equivalent. Concentrations of nitrite plus nitrate in samples preserved with sulfuric acid and chilling (table 7) were within the 95-percent confidence level of the reporting levels for concentrations in samples preserved by the other two methods and also may be considered equivalent to them.

The comparison of orthophosphate results for samples preserved with mercuric chloride and chilling and samples preserved by chilling only (table 5) indicates that all the sample pairs are statistically equivalent. The correlation coefficients for orthophosphate show that there was high variability in the chilled-only samples in the BSP. Even though the high variability resulted in large MPD's, all the results of sample pairs analyzed for orthophosphate were within one standard deviation. Preservation of orthophosphate samples with sulfuric acid and chilling was not investigated because the NWQL does not routinely analyze for this method.

\section{CONCLUSIONS}

Concentrations of nutrients in water samples from 28 wells at the INEL were not affected measurably by the three preservation methods considered for this study. The concentrations of ammonia, nitrite, nitrite plus nitrate, and orthophosphate in field-filtered samples preserved by treating with mercuric chloride and chilling were statisti-cally equivalent to concentrations of the same nutrients in samples preserved by chilling only. Although the two nutrient analyses (ammonia and nitrite plus nitrate) that were done on samples preserved with sulfuric acid and chilling could not be compared statistically, the results were within the 95-percent confidence level of the results for the samples preserved by the other two methods and can be considered equivalent. Results of this study indicate that discontinuing the use of mercuric chloride as a preservation method for nutrients in water samples will not affect the comparability of the data collected from wells at the INEL before and after October 1, 1994.

\section{REFERENCES CITED}

Bartholomay, R.C., 1993, Concentrations of tritium and strontium-90 in water from selected wells at the Idaho National Engineering Laboratory after purging one, two, and three borehole volumes: U.S. Geological Survey Water-Resources Investigations Report 93-4201 (DOE/ID-22111), 21 p.

Bartholomay, R.C., Orr, B.R., Liszewski, M.J., and Jensen, R.G., 1995, Hydrologic conditions and distribution of selected radiochemical and chemical constituents in water, Snake River Plain aquifer, Idaho National Engineering Laboratory, Idaho, 1989 through 1991: U.S. Geological Survey Water-Resources Investigations Report 95-4175 (DOE/ID22123), $47 \mathrm{p}$.

Brezonik, P.L., and Lee, G.F., 1966, Preservation of water samples for inorganic nitrogen analyses with mercuric chloride: Intemational Joumal of Air and Water Pollution, v. 10, p. 549-553.

Cecil, L.D., Knobel, L.L., Wegner, S.J., and Moore, L.L., 1989, Evaluation of field sampling and preservation methods for strontium-90 in ground water at the Idaho National Engineering Laboratory, Idaho: U.S. Geological Survey Water-Resources Investigations Report 89-4146 (DOE/ID22083), 24 p.

Claassen, H.C., 1982, Guidelines and techniques for obtaining water samples that accurately represent the water chemistry of an aquifer: U.S. Geological Survey Open-File Report 82-1024, 49 p.

Fishman, M.J., ed., 1993, Methods of analysis by the U.S. Geological Survey National Water Quality Laboratory-determination of inorganic and organic constituents in water and fluvial sediments: U.S. Geological Survey Open-File Report 93-125, 217 p. 
Fishman, M.J., Schroder, L.J., and Shockey, M.W., 1986, Evaluation of methods for preservation of water samples for nutrient analysis: Journal of Environmental Studies, v. 26, p. 231-238.

Garabedian, S.P., 1986, Application of a parameter-estimation technique to modeling the regional aquifer underlying the eastem Snake River Plain, Idaho: U.S. Geological Survey Water-Supply Paper 2278, 60 p.

Hardy, M.A., Leahy, P.P., and Alley, W.M., 1989, Well installation and documentation, and ground-water sampling protocols for the pilot National Water-Quality Assessment Program: U.S. Geological Survey Open-File Report 89-396, 36 p.

Horowitz, A.J., Demas, C.R., Fitzgerald, K.K., Miller, T.L., and Rickert, D.A., 1995, U.S. Geological Survey protocol for the collection and processing of surface-water samples for the subsequent determination of inorganic constituents in filtered water: U.S. Geological Survey Open-File Report 94-539, 57 p.

Knobel, L.L., and Mann, L.J., 1993, Sampling for purgeable organic compounds using positivedisplacement piston and centrifugal submersible pumps-a comparative study: Ground Water Monitoring and Remediation, v. 13, no. 2 , p. $142-148$.

Lucey, K.J., 1990, QADATA User's Manual: an interactive computer program for the retrieval and analysis of the results from the external blind sample quality-assurance project of the U.S. Geological Survey: U.S. Geological Survey Open-File Report 90-162, $53 \mathrm{p}$.

Maloney, T.J., Ludtke, A.S., and Krizman, T.L., 1993, Quality assurance for routine water analysis in the laboratories of the U.S. Geological Survey for water year 1990: U.S. Geological Survey Water-Resources Investigations Report 93-4082, 145 p.
Orr, B.R., and Cecil, L.D., 1991, Hydrologic conditions and distribution of selected chemical constituents in water, Snake River Plain aquifer, Idaho National Engineering Laboratory, Idaho, 1986 to 1988: U.S. Geological Survey Water-Resources Investigations Report 91-4047 (DOE/ID22096), $56 \mathrm{p}$.

Orr, B.R., Cecil, L.D., and Knobel, L.L., 1991, Background concentrations of selected radionuclides, organic compounds, and chemical constituents in ground water in the vicinity of the Idaho National Engineering Laboratory: U.S. Geological Survey WaterResources Investigations Report 91-4015 (DOE/ID-22094), 52 p.

Patton, C.J., and Truitt, E.P., 1995, U.S. Geological Survey nutrient preservation experiment-nutrient concentration data for surface-, ground-, and municipal-supply water samples and quality-assurance samples: U.S. Geological Survey Open-File Report 95-141, 140 p.

Stevens, H.H., Jr., Ficke, J.F., and Smoot, G.F., 1975, Water temperature-influential factors, field measurement, and data presentation: U.S. Geological Survey Techniques of Water-Resources Investigations, book 5, chap. D1, 65 p.

Volk, William, 1969, Applied statistics for engineers ( $2 \mathrm{~d}$ ed.): New York, McGraw-Hill Book Company, 415 p.

Wegner, S.J., 1989, Selected quality assurance data for water samples collected by the U.S. Geological Survey, Idaho National Engineering Laboratory, Idaho, 1980 to 1988: U.S. Geological Survey Water-Resources Investigations Report 89-4168 (DOE/ID-22085), $91 \mathrm{p}$.

Whitehead, R.L., 1986, Geohydrologic framework of the Snake River Plain, Idaho and eastern Oregon: U.S. Geological Survey Hydrologic Investigations Atlas HA-681, scale $1: 1,000,000,3$ sheets. 
Williams, L.M., 1996, Evaluation of quality assurance/quality control data collected by the U.S. Geological Survey for water-quality activities at the Idaho National Engineering Laboratory, Idaho, 1989 through 1993: U.S. Geological Survey Water-Resources Investigations Report 96-4148, (DOE/ID22129), $116 \mathrm{p}$.
Wood, W.W., 1981, Guidelines for collection and field analysis of ground-water samples for selected unstable constituents: U.S. Geological Survey Techniques of WaterResources Investigations, book 1, chap. D2, $24 \mathrm{p}$.

Table 1. Linear least-squared equations used for determining the most probable deviations for results of nutrient analyses

[Least-squared equations for mercuric chloride preservation (Ludtke, USGS, written commun., 1994) were determined from data prior to October 1994. Least-squared equations for chilled samples (Ludtke, USGS, written commun., 1996) were determined from data of chilled-only samples. X, analytical result for sample preservation with mercuric chloride and chilling. $Y$, analytical result for sample preserved with chilling only. MPD, most probable deviation. $\mathrm{HgCl}_{2}$, mercuric chloride. Units are in milligrams per liter]

\begin{tabular}{|c|c|c|c|c|}
\hline Constituent & $\begin{array}{c}\text { Equation to determine } \\
\text { MPD } \\
\left(\mathrm{HgCl}_{2} \text { and chilling) }\right.\end{array}$ & $\begin{array}{l}\text { Correlation } \\
\text { coefficient }\end{array}$ & $\begin{array}{c}\text { Equation to determine } \\
\text { MPD } \\
\text { (chilling only) }\end{array}$ & $\begin{array}{l}\text { Correlation } \\
\text { coefficient }\end{array}$ \\
\hline Ammonia as nitrogen & $0.056 \mathrm{X}+0.018$ & 0.958 & $.016 Y+0.065$ & 0.066 \\
\hline $\begin{array}{l}\text { Nitrite plus nitrate as } \\
\text { nitrogen }\end{array}$ & $.040 \mathrm{X}+0.02$ & .622 & $.037 \mathrm{Y}+0.017$ & .920 \\
\hline $\begin{array}{c}\text { Orthophosphate as } \\
\text { phosphorus }\end{array}$ & $.072 \mathrm{X}-0.005$ & .854 & $.055 Y+0.026$ & .307 \\
\hline
\end{tabular}


Table 2. Comparison of ammonia results obtained from field-filtered samples preserved with mercuric chloride and chilling and samples preserved by chilling only, Idaho National Engineering Laboratory

[Well identifier: see figures $1-2$ for location. $\mathrm{HgCl}_{2}$, mercuric chloride. Z-value: see section on statistical comparisons for explanation. Analytical results in milligrams per liter. <, less than]

\begin{tabular}{|c|c|c|c|c|}
\hline Well identifier & Date sampled & $\begin{array}{l}\text { Ammonia as nitrogen } \\
\text { ( } \mathrm{HgCl}_{2} \text { and chilling) }\end{array}$ & $\begin{array}{l}\text { Ammonia as nitrogen } \\
\text { (chilling only) }\end{array}$ & Z-value \\
\hline USGS 4 & $10 / 24 / 94$ & $<0.01$ & $<0.015$ & 0 \\
\hline 7 & $10 / 14 / 94$ & $<.01$ & $<.015$ & 0 \\
\hline 12 & $10 / 27 / 94$ & .01 & $<.015$ & 0 \\
\hline 15 & $11 / 07 / 94$ & $<.01$ & $<.015$ & 0 \\
\hline 17 & $10 / 27 / 94$ & .02 & $<.015$ & .07 \\
\hline 37 & $10 / 07 / 94$ & .01 & $<.015$ & 0 \\
\hline 40 & $10 / 18 / 94$ & .01 & $<.015$ & 0 \\
\hline 42 & $10 / 18 / 94$ & .01 & $<.015$ & 0 \\
\hline 43 & $10 / 21 / 94$ & .01 & $<.015$ & 0 \\
\hline 77 & $10 / 07 / 94$ & .01 & $<.015$ & 0 \\
\hline 84 & $10 / 18 / 94$ & .02 & $<.015$ & .07 \\
\hline 86 & $10 / 04 / 94$ & $<.01$ & $<.015$ & 0 \\
\hline 89 & $10 / 07 / 94$ & $<.01$ & $<.015$ & 0 \\
\hline 97 & $11 / 10 / 94$ & $<.01$ & $<.015$ & 0 \\
\hline 98 & $11 / 09 / 94$ & .02 & $<.015$ & .07 \\
\hline 99 & $11 / 09 / 94$ & $<.01$ & $<.015$ & 0 \\
\hline 102 & $11 / 08 / 94$ & $<.01$ & $<.015$ & 0 \\
\hline 104 & $9 / 30 / 94$ & .01 & $<.015$ & 0 \\
\hline 105 & $10 / 03 / 94$ & $<.01$ & $<.015$ & 0 \\
\hline 107 & $10 / 05 / 94$ & $<.01$ & $<.015$ & 0 \\
\hline 119 & $10 / 06 / 94$ & $<.01$ & $<.015$ & 0 \\
\hline MTR Test & $9 / 28 / 94$ & .01 & $<.015$ & 0 \\
\hline NRF-1 & $11 / 08 / 94$ & .01 & $<.015$ & 0 \\
\hline NRF-2 & $11 / 08 / 94$ & .02 & $<.015$ & .07 \\
\hline NRF-3 & $11 / 08 / 94$ & .02 & $<.015$ & .07 \\
\hline NRF-4 & $11 / 10 / 94$ & .01 & $<.015$ & 0 \\
\hline NRF-7 & $11 / 04 / 94$ & $<.01$ & $<.015$ & 0 \\
\hline WSI-1 & $11 / 09 / 94$ & .02 & .02 & .00 \\
\hline
\end{tabular}


Table 3. Comparison of nitrite results obtained from field-filtered samples preserved with mercuric chloride and chilling and samples preserved by chilling only, Idaho National Engineering Laboratory

[Well identifier: see figures $1-2$ for location. $\mathrm{HgCl}_{2}$, mercuric chloride. $\mathrm{Z}$-value: see section on statistical comparisons for explanation. Analytical results in milligrams per liter. $<$, less than]

\begin{tabular}{|c|c|c|c|c|}
\hline Well identifier & Date sampled & $\begin{array}{l}\text { Nitrite as nitrogen } \\
\left(\mathrm{HgCl}_{2} \text { and chilling) }\right.\end{array}$ & $\begin{array}{l}\text { Nitrite as nitrogen } \\
\text { (chilling only) }\end{array}$ & Z-value \\
\hline USGS 4 & $10 / 24 / 94$ & $<0.01$ & $<0.01$ & 0 \\
\hline 7 & $10 / 14 / 94$ & $<.01$ & $<.01$ & 0 \\
\hline 12 & $10 / 27 / 94$ & $<.01$ & $<.01$ & 0 \\
\hline 15 & $11 / 07 / 94$ & $<.01$ & $<.01$ & 0 \\
\hline 17 & $10 / 27 / 94$ & $<.01$ & $<.01$ & 0 \\
\hline 37 & $10 / 07 / 94$ & $<.01$ & $<.01$ & 0 \\
\hline 40 & $10 / 18 / 94$ & $<.01$ & $<.01$ & 0 \\
\hline 42 & $10 / 18 / 94$ & $<.01$ & $<.01$ & 0 \\
\hline 43 & $10 / 21 / 94$ & $<.01$ & $<.01$ & 0 \\
\hline 77 & $10 / 07 / 94$ & $<.01$ & $<.01$ & 0 \\
\hline 84 & $10 / 18 / 94$ & $<.01$ & $<.01$ & 0 \\
\hline 86 & $10 / 04 / 94$ & $<.01$ & $<.01$ & 0 \\
\hline 89 & $10 / 07 / 94$ & $<.01$ & $<.01$ & 0 \\
\hline 97 & $11 / 10 / 94$ & $<.01$ & $<.01$ & 0 \\
\hline 98 & $11 / 09 / 94$ & $<.01$ & $<.01$ & 0 \\
\hline 99 & $11 / 09 / 94$ & $<.01$ & $<.01$ & 0 \\
\hline 102 & $11 / 08 / 94$ & $<.01$ & $<.01$ & 0 \\
\hline 104 & $9 / 30 / 94$ & $<.01$ & $<.01$ & 0 \\
\hline 105 & $10 / 03 / 94$ & $<.01$ & $<.01$ & 0 \\
\hline 107 & $10 / 05 / 94$ & $<.01$ & $<.01$ & 0 \\
\hline 119 & $10 / 06 / 94$ & $<.01$ & $<.01$ & 0 \\
\hline MTR Test & $9 / 28 / 94$ & $<.01$ & $<.01$ & 0 \\
\hline NRF-1 & $11 / 08 / 94$ & $<.01$ & $<.01$ & 0 \\
\hline NRF-2 & $11 / 08 / 94$ & $<.01$ & $<.01$ & 0 \\
\hline NRF-3 & $11 / 08 / 94$ & $<.01$ & $<.01$ & 0 \\
\hline NRF-4 & $11 / 10 / 94$ & $<.01$ & $<.01$ & 0 \\
\hline NRF-7 & $11 / 04 / 94$ & $<.01$ & $<.01$ & 0 \\
\hline WSI-1 & $11 / 09 / 94$ & $<.01$ & $<.01$ & 0 \\
\hline
\end{tabular}


Table 4. Comparison of nitrite plus nitrate results obtained from field-filtered samples preserved with mercuric chloride and chilling and samples preserved by chilling only, Idaho National Engineering Laboratory

[Well identifier: see figures $1-2$ for location. $\mathrm{HgCl}_{2}$, mercuric chloride. $\mathrm{Z}$-value: see section on statistical comparisons for explanation. Analytical results in milligrams per liter]

\begin{tabular}{|c|c|c|c|c|}
\hline Well identifier & Date sampled & $\begin{array}{l}\text { Nitrite plus nitrate } \\
\text { as nitrogen } \\
\left(\mathrm{HgCl}_{2} \text { and chilling }\right)\end{array}$ & $\begin{array}{l}\text { Nitrite plus nitrate } \\
\text { as nitrogen } \\
\text { (chilling only) }\end{array}$ & Z-value \\
\hline USGS 4 & $10 / 24 / 94$ & 4.7 & 4.7 & 0.00 \\
\hline 7 & $10 / 14 / 94$ & .38 & .4 & .42 \\
\hline 12 & $10 / 27 / 94$ & 2.0 & 2.1 & .73 \\
\hline 15 & $11 / 07 / 94$ & .35 & .35 & .00 \\
\hline 17 & $10 / 27 / 94$ & .31 & .34 & .68 \\
\hline 37 & $10 / 07 / 94$ & 3.0 & 3.0 & .00 \\
\hline 40 & $10 / 18 / 94$ & 5.3 & 5.5 & .62 \\
\hline 42 & $10 / 18 / 94$ & 2.1 & 2.2 & .70 \\
\hline 43 & $10 / 21 / 94$ & 6.1 & 6.1 & .00 \\
\hline 77 & $10 / 07 / 94$ & 4.4 & 4.4 & .00 \\
\hline 84 & $10 / 18 / 94$ & 1.1 & 1.1 & .00 \\
\hline 86 & $10 / 04 / 94$ & 1.5 & 1.6 & .91 \\
\hline 89 & $10 / 07 / 94$ & 1.8 & 1.8 & .00 \\
\hline 97 & $11 / 10 / 94$ & 2.0 & 2.0 & .00 \\
\hline 98 & $11 / 09 / 94$ & 1.1 & 1.0 & 1.19 \\
\hline 99 & $11 / 09 / 94$ & 1.6 & 1.5 & .90 \\
\hline 102 & $11 / 08 / 94$ & 1.9 & 1.9 & .00 \\
\hline 104 & $9 / 30 / 94$ & .66 & .69 & .48 \\
\hline 105 & $10 / 03 / 94$ & .68 & .68 & .00 \\
\hline 107 & $10 / 05 / 94$ & .99 & 1.1 & 1.33 \\
\hline 119 & $10 / 06 / 94$ & 1.3 & 1.3 & .00 \\
\hline MTR Test & $9 / 28 / 94$ & 1.1 & 1.2 & 1.13 \\
\hline NRF-1 & $11 / 08 / 94$ & 1.9 & 1.9 & .00 \\
\hline NRF-2 & $11 / 08 / 94$ & 2.0 & 2.0 & .00 \\
\hline NRF-3 & $11 / 08 / 94$ & 1.9 & 1.9 & .00 \\
\hline NRF-4 & $11 / 10 / 94$ & 2.2 & 2.2 & .00 \\
\hline NRF-7 & $11 / 04 / 94$ & .47 & .46 & .19 \\
\hline WSI-1 & $11 / 09 / 94$ & 4.2 & 4.3 & .39 \\
\hline
\end{tabular}


Table 5. Comparison of orthophosphate results obtained from field-filtered samples preserved with mercuric chloride and chilling and samples preserved by chilling only, Idaho National Engineering Laboratory

[Well identifier: see figures $1-2$ for location. $\mathrm{HgCl}_{2}$, mercuric chloride. $\mathrm{Z}$-value: see section on statistical comparisons for explanation. Analytical results in milligrams per liter. <, less than]

\begin{tabular}{|c|c|c|c|c|}
\hline Well identifier & Date sampled & $\begin{array}{l}\text { Orthe yhosphate as } \\
\text { phosphorus } \\
\text { (HgCl } 2 \text { and chilling) }\end{array}$ & $\begin{array}{l}\text { Orthophosphate as } \\
\text { phosphorus } \\
\text { (chilling only) }\end{array}$ & Z-value \\
\hline USGS 4 & $10 / 24 / 94$ & 0.01 & $<0.01$ & 0 \\
\hline 7 & $10 / 14 / 94$ & $<.01$ & .01 & 0 \\
\hline 12 & $10 / 27 / 94$ & .02 & $<.01$ & .37 \\
\hline 15 & $11 / 07 / 94$ & .01 & .02 & .36 \\
\hline 17 & $10 / 27 / 94$ & .02 & $<.01$ & .37 \\
\hline 37 & $10 / 07 / 94$ & .01 & .02 & .36 \\
\hline 40 & $10 / 18 / 94$ & .01 & .02 & .36 \\
\hline 42 & $10 / 18 / 94$ & .02 & .02 & .00 \\
\hline 43 & $10 / 21 / 94$ & .01 & $<.01$ & 0 \\
\hline 77 & $10 / 07 / 94$ & .01 & .02 & .36 \\
\hline 84 & $10 / 18 / 94$ & $<.01$ & .02 & .36 \\
\hline 86 & $10 / 04 / 94$ & .01 & .02 & .36 \\
\hline 89 & $10 / 07 / 94$ & $<.01$ & .01 & 0 \\
\hline 97 & $11 / 10 / 94$ & .02 & .02 & .00 \\
\hline 98 & $11 / 09 / 94$ & .02 & .02 & .00 \\
\hline 99 & $11 / 09 / 94$ & .02 & .02 & .00 \\
\hline 102 & $11 / 08 / 94$ & .02 & .02 & .00 \\
\hline 104 & $9 / 30 / 94$ & $<.01$ & .01 & 0 \\
\hline 105 & $10 / 03 / 94$ & $<.01$ & .01 & 0 \\
\hline 107 & $10 / 05 / 94$ & $<.01$ & .01 & 0 \\
\hline 119 & $10 / 06 / 94$ & $<.01$ & $<.01$ & 0 \\
\hline MTR Test & $9 / 28 / 94$ & $<.01$ & .02 & .36 \\
\hline NRF-1 & $11 / 08 / 94$ & .02 & .02 & .00 \\
\hline NRF-2 & $11 / 08 / 94$ & .02 & .02 & .00 \\
\hline NRF-3 & $11 / 08 / 94$ & .02 & .02 & .00 \\
\hline NRF-4 & $11 / 10 / 94$ & .02 & .02 & .00 \\
\hline NRF-7 & $11 / 04 / 94$ & .01 & .02 & .36 \\
\hline WSI-1 & $11 / 09 / 94$ & .01 & .01 & .00 \\
\hline
\end{tabular}


Table 6. Ammonia results obtained from field-filtered samples preserved with sulfuric acid and chilling, samples preserved with mercuric chloride and chilling, and samples preserved by chilling only, Idaho National Engineering Laboratory

[Well identifier: see figures 2 for location. $\mathrm{H}_{2} \mathrm{SO}_{4}$, sulfuric acid. $\mathrm{HgCl}_{2}$, mercuric chloride. Analytical results in milligrams per liter. $<$, less than]

\begin{tabular}{rcccc}
\hline Well identifier & Date sampled & $\begin{array}{c}\text { Ammonia as nitrogen } \\
\left(\mathbf{H}_{2} \mathbf{S O}_{4} \text { and chilling) }\right.\end{array}$ & $\begin{array}{c}\text { Ammonia as nitrogen } \\
\left(\mathbf{H g C l}_{2} \text { and chilling }\right)\end{array}$ & $\begin{array}{c}\text { Ammonia as nitrogen } \\
\text { (chilling only) }\end{array}$ \\
\hline USGS 12 & $10 / 27 / 94$ & $<0.015$ & 0.01 & $<0.015$ \\
15 & $11 / 07 / 94$ & $<.015$ & $<.01$ & $<.015$ \\
17 & $10 / 27 / 94$ & $<.015$ & .02 & $<.015$ \\
97 & $11 / 10 / 94$ & .04 & $<.01$ & $<.015$ \\
98 & $11 / 09 / 94$ & $<.015$ & .02 & $<.015$ \\
99 & $11 / 09 / 94$ & $<.015$ & $<.01$ & $<.015$ \\
102 & $11 / 08 / 94$ & $<.015$ & $<.01$ & $<.015$ \\
NRF-1 & $11 / 08 / 94$ & $<.015$ & .01 & $<.015$ \\
NRF-2 & $11 / 08 / 94$ & $<.015$ & .02 & $<.015$ \\
NRF-3 & $11 / 08 / 94$ & $<.015$ & .02 & $<.015$ \\
NRF-4 & $11 / 10 / 94$ & $<.015$ & .01 & $<.015$ \\
NRF-7 & $11 / 04 / 94$ & $<.015$ & $<.01$ & $<.015$ \\
WSI-1 & $11 / 09 / 94$ & $<.015$ & .02 & .02 \\
\hline
\end{tabular}


Table 7. Nitrite plus nitrate results obtained from field-filtered samples preserved with suffuric acid and chilling, samples preserved with mercuric chloride and chilling, and samples preserved by chilling only, Idaho National Engineering Laboratory

[Well identifier: see figure 2 for location. $\mathrm{H}_{2} \mathrm{SO}_{4}$, sulfuric acid. $\mathrm{HgCl}_{2}$, mercuric chloride. Analytical results in milligrams per liter]

\begin{tabular}{rcccc}
\hline Well identifier & Date sampled & $\begin{array}{c}\text { Nitrite plus nitrate } \\
\left(\mathbf{H}_{2} \mathbf{S O}_{4} \text { and chilling) }\right.\end{array}$ & $\begin{array}{c}\text { Nitrite plus nitrate } \\
\left(\mathbf{H g C l}_{2} \text { and chilling) }\right.\end{array}$ & $\begin{array}{c}\text { Nitrite plus nitrate } \\
\text { (chilling only) }\end{array}$ \\
\hline USGS 12 & $10 / 27 / 94$ & 2.1 & 2.0 & 2.1 \\
15 & $11 / 07 / 94$ & .37 & .35 & .35 \\
17 & $10 / 27 / 94$ & .30 & .31 & .34 \\
97 & $11 / 10 / 94$ & 2.1 & 2.0 & 2.0 \\
98 & $11 / 09 / 94$ & 1.1 & 1.1 & 1.0 \\
99 & $11 / 09 / 94$ & 1.6 & 1.6 & 1.5 \\
102 & $11 / 08 / 94$ & 1.9 & 1.9 & 1.9 \\
NRF-1 & $11 / 08 / 94$ & 1.9 & 1.9 & 1.9 \\
NRF-2 & $11 / 08 / 94$ & 1.9 & 2.0 & 2.0 \\
NRF-3 & $11 / 08 / 94$ & 1.9 & 1.9 & 1.9 \\
NRF-4 & $11 / 10 / 94$ & 2.1 & 2.2 & 2.2 \\
NRF-7 & $11 / 04 / 94$ & .45 & .47 & .46 \\
WSI-1 & $11 / 09 / 94$ & 4.1 & 4.2 & 4.3 \\
\hline
\end{tabular}

